\title{
Teletandem and telepresence: Rethinking the cultural component in language teaching and language teacher education
}

\author{
Teletandem e telepresença: Repensando o \\ componente cultural na educação de línguas $e$ \\ na educação do professor de línguas
}

Ana Cristina Biondo Salomão

(UNESP - Universidade Estadual Paulista, Brazil)

\begin{abstract}
This articles discusses some of the results of a qualitative ethnographic research on foreign language teacher's conceptions of culture in an extension course for continuing education in the virtual collaborative learning context of "Teletandem Brazil: foreign languages for all", UNESP. The results have implications for the fields of language teaching and learning mediated by new technologies and teacher education. They suggest that telepresence in teletandem provided a means for dialogically undergoing the complexities of cultural experiences. Grounded in real world interaction, these experiences can lead to the change of the knowledge base of language teacher education for intercultural communication and the teaching and learning of culture. Culture can, then, be dissociated from the idea of a homogeneous, fixed and transparent body of knowledge.
\end{abstract}

Key-words: foreign language teaching; foreign language teacher education; teletandem; culture. 


\section{RESUMO}

Este artigo discute alguns resultados de uma pesquisa etnográfica qualitativa acerca das concepções de cultura, por professores de línguas estrangeiras durante um curso de extensão para a formação contínua, no contexto de aprendizagem colaborativa virtual de "Teletandem Brasil: línguas estrangeiras para todos", UNESP. Os resultados têm implicações para os campos de ensino e aprendizagem mediadas pelas novas tecnologias e da formação de professores. A telepresença em teletandem parece fornecer um meio para considerar as complexidades de experiências culturais de modo dialógico. Calcadas na interação do mundo real, tais experiências podem levar à transformação da base de conhecimento da formação de professores de línguas para a comunicação intercultural e do ensino e aprendizagem de cultura. A cultura pode, então, ser dissociada da idéia de um corpo homogeneo, fixo e transparente de conhecimento.

Palavras-chave: ensino de línguas estrangeiras; formação de professores de línguas estrangeiras; de teletandem; cultura.

\section{Introduction}

The possibility of intercultural communication mediated by new technologies nowadays poses for Applied Linguistics the important task of investigating the impact of "cultural globalization" over the areas of foreign language teaching and teacher education. Contemporary authors such as Rajagopalan (2003), Kumaravadivelu (2006), Risager (2006, 2007), Holliday, Hyde and Kullman (2010), among others, point to the necessity of thinking about language teaching from a local and global perspective that brings up cultural, discursive and linguistic flows and seizes the political character of the relationship between language, culture and society, in order to enable learners to interact with people who have other ways of thinking and acting.

This article brings some of the results of a study ${ }^{1}$ that analyzes a hybrid course for in-service teachers in the virtual collaborative learning

1. This article brings some of the results of our doctoral research (Salomão, 2012)), which was funded by FAPESP (São Paulo Research Foundation), and was presented as a paper at the I INFLIT (First International Meeting on Foreign Language - Learning in Tandem: to participate in this International Meeting (Process number 2013/23002-9). 
context of the project "Teletandem Brazil: foreign languages for all", from São Paulo State University - UNESP. In this project, Brazilian teachers of Spanish as a foreign language took part in a blended tandem learning course, communicating through Skype with Uruguayan and Argentinean teachers of Portuguese as a foreign language. The aim of the study was to verify the Brazilian teachers' concepts and beliefs concerning language and culture and how the teletandem interactions affected them.

The theoretical framework is anchored in the sociocultural theory (Vygotsky, 1994; Lantolf, 2000) and its perspective for language teacher education (JOHNSON, 2009), new technologies and teacher training (Chappelle, 2006; Hall, Knox, 2009), and culture in language teaching (Kramsch, 2006, 2009, 2011; Kumaravadivelu, 2006; 2008; Risager, 2006, 2007).

We firstly present the framework of online collaborative language learning in teletandem, as well as the context of our study. Then, we discuss the results and the implications of teletandem interactions to the teachers' view of culture.

\section{Theoretical Framework}

\section{Teletandem - online collaborative language learning}

Online collaboration is growing rapidly due to the convergence and spread of videoconferencing tools, such as Skype, ooVoo, among others in the Internet. Teletandem is a collaborative language learning model based on tandem learning, which makes use of such videoconferencing tools, specially Skype, to put people in contact to learn and teach foreign languages collaboratively. Each person in the partnership teaches his or her own language (or language in which he or she is proficient in) to the other. In this way, we can say that foreign language learning in teletandem involves pairs of (native or competent) speakers whose aim is to learn each other's language by means of bilingual conversation sessions (Telles; Vassallo, 2006; Vassallo; Telles, 2006).

Teletandem processes are carried out on bases of commonly agreed and shared principles of reciprocity and autonomy between the 
participants. They are autonomous in their learning but they can resort to a teacher's professional mediation if they wish (see Telles, in this issue). Intertwined with language learning in this collaborative model is the learning/teaching of culture.

Within an autonomous, reciprocal and collaborative learning context, each partner becomes both a learner of the foreign language and a tutor of his/her mother tongue (or language in which he/she feels proficient). A teletandem session usually takes one to two hours a week (half of the time for each language). In the session, teletandem partners talk about a topic (which can be previously chosen), exchanging cultural information and giving each other feedback on language use. They also reflect on their own learning focusing upon content, culture, form, lexicon and on the processes of teletandem interactions.

\section{Method}

In the first years of the project Teletandem Brazil, it was mostly undergraduate students who participated as teletandem partners with undergraduate students from a number of different countries whose native languages were Spanish, French, English or Italian. In 2008, a hybrid course (partly on campus/ partly web-based - TelEduc) was offered by the Teletandem Project for in-service Brazilian teachers of Spanish as a foreign language from public schools in Brazil, in which cultural aspects were addressed theoretically and practically through the interactions.

These Brazilian teachers made regular teletandem sessions with Uruguayan and Argentinean teachers of Portuguese as a foreign language, exchanging cultural information and were supervised by the teacher educators in charge of the course. The Uruguayan and Argentinean teachers had previously been introduced to teletandem in a course given by the Teletandem group coordinator in Uruguay (December 2007). They were also enrolled in the TelEduc environment - a virtual learning environment for distance education created in Brazil in which courses are offered on the Internet - and could take part in the activities proposed if they wished, but this was not mandatory for them. 
There were eight Brazilian teachers, whose experience of teaching Spanish as a foreign language ranged from 6 to 20 years, who made regular teletandem sessions (from May to September of 2009) with Uruguayan and Argentinean teachers through Skype. As mentioned before, they were enrolled in a teacher education course, entitled "Teacher education for teaching/learning foreign languages in tandem", in which they had four classes (of four hours each) on campus with Brazilian professors and educators from a renowned university in the state of São Paulo. They also interacted through activities, forums and chats in the virtual environment of the course hosted at TelEduc (Figure 1). The topics addressed were the principles of tandem and Teletandem learning, the Internet tools used in this kind of virtual communication, and some research results on Teletandem mediation, autonomy, evaluation and self-evaluation, culture, correction and feedback.

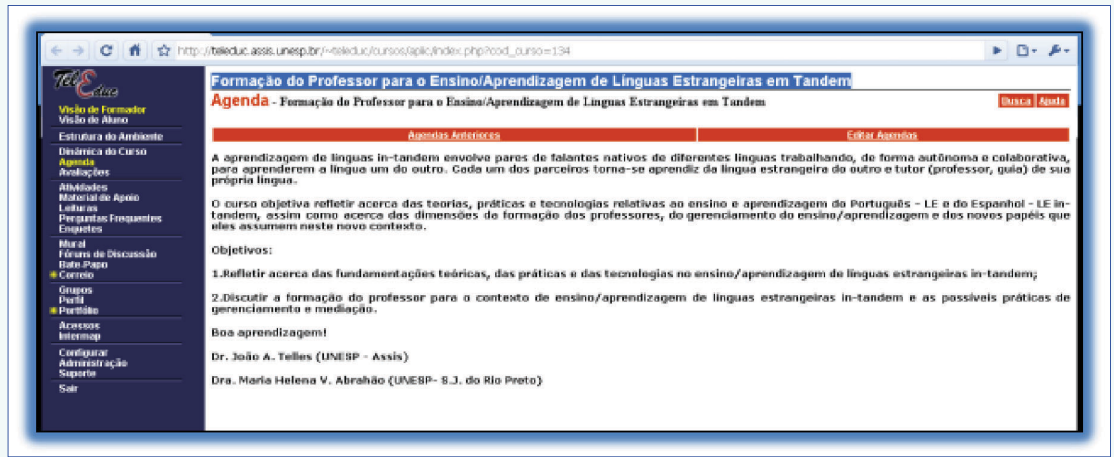

Figure 1 - Virtual learning environment of the course in the Internet (TelEduc)

The data collection involved methods of qualitative studies with ethnographic basis, such as the intense and long-term participation of the researcher in the studied context. The collection was made through careful register of all facts and events, by means of a number of different instruments (autobiographies, questionnaires, interviews, the recording of the on-campus classes and the teletandem sessions) and was followed by analytical reflection over the material gathered through an interpretative approach (André, 2000; Bogdan; Biklen, 1982; Erickson, 1986; Silverman, 2001). The data were firstly analyzed separately, by means of categorization of teachers' expressed beliefs and concepts, 
and then they were triangulated in order to equate the multiple views and validate the findings (MCDONOUGH; MCDONOUGH, 1997).

\section{Results}

\section{Teachers' view of culture}

According to the data analysis, the concept of culture of this group of teachers was seen as a body of knowledge about the products, practices and perspectives of a people, generally associated with a nation state, in a relationship that often goes from collectivity to the individual and presents itself in language as elements that distinguish people in their ways of expressing themselves. The following are some excerpts of teachers' voices during the course that illustrate such findings.

(Culture) Every manifestation of a group of people. Culture is everything that people do. I consider culture the way of living of each one.

(Sonia, activity 2, TelEduc, 06/19/2009)

(Culture) Any learning past from one to another within a geographic area with specific characteristics of the environment in which there is coexistence.

(Elisa, activity 2, TelEduc, 07/14/2009)

Researcher: What is culture?

Rosana: Culture is the way of life of a people, their beliefs, customs, values, food, etc.

(Interview)

Beth: I think that all this information we pass to them, this is culture, understand? I talk about the people, the way they talk, the way they eat.

(Interview)

(19:39:05) Beth speaks to Pablo: I prefer Spanish people

$(\ldots)$

(19:40:17) Beth speaks to all: I would like to talk to someone from Madrid. 
(19:40:43) Ana Cristina speaks to all: Why do prefer the Spanish, Beth? Why the ones from Madrid?

(19:41:20) Beth speaks to all: Besides being "guapos" (handsome) and smelling good, they are very intelligent, they are always in the cafes reading.

(19:41:27) Fabiana speaks to all: because I like their (Spanish) culture and would still for sure have a lot to learn, even having lived there for 7 months

(...)

(20:24:46) Pablo speaks to all: And then the students ask you: But have you been there, teacher? Have you eaten this? Have you seen this monument?

(20:27:01) Pablo speaks to all: and a lot of my colleagues are asked: PROFESSOR, HAVE YOU EVER TRAVELED TO A COUNTRY WHERE THE SPANISH LANGUAGE IS SPOKEN? (...) it falls in the issue of veracity.

(Chat on TelEduc, "Intercultural communication", 07/30/2009)

Intercultural communication is having contact with other cultures and being open to them - to understand them, accept them and even incorporate them.

(Keila, activity 2, TelEduc 08/15/2009)

Fabiana: (...) and students asked me: "Professor, will we have a culture lesson today?" (...) "Teacher, you taught a class about culture? And I missed it". They used to love it. And then I started to work more with this part.

(Interview)

(20:17:05) Fabiana speaks to all: they love to talk about culture

(20:17:32) Fabiana speaks to all: I have a class that every time asks me to say something about the culture of Spain.

(...)

(20:23:10) Teacher educator talks to Prof. from Uruguay: Before teletandem did you use to talk to your students about Brazil?

(20:25:54) Uruguayan teacher speaks to all: yeah, always, I just say that Portugal is for you what Spain is for us, the dates of discovery a little bit of history and then culture.

(20:27:16) Beth talks to Uruguayan teacher: add me to your msn and I will send you what you need to talk to the students (...)

(Chat on TelEduc, "Intercultural competence of language teachers", 08/12/2009) 
As can be seen in the excerpts, these teachers' expressed beliefs and concepts about culture and the teaching of culture in the language classroom are connected to having knowledge about products, practices and perspectives of a group or groups of people. This knowledge was usually reported by teachers as generalizable, featuring stereotypes and essentialist views of homogenization that put culture as coincidental with countries, regions and continents. According to Holliday (2005, p.17), such psychogeographical view of culture generally implies that one can 'visit' a culture while traveling and that cultures "contain mutually exclusive types of behavior so that people 'from' or 'in' French culture are essentially different from those 'from' or 'in' Chinese culture".

Most teachers also regarded culture as a static monolithic block, which is transparent, conflict-free and independent from interpretations. Colonialist discourses of superiority of Europeans are reproduced, helping to create stereotypical views, which albeit sometimes positive, depict a fixed reality, deprived from subjectivity, context, discourse and ideology.

Beth's comment in the last excerpt ("add me to your msn and I will send you what you need to talk to the students") illustrates the concept of teaching culture as a block of information to be transmitted. In fact, such conception is apparently manifested in teaching culture, in these teachers' views, as knowledge 'about' the 'other' to be transmitted, compared with their own country, copied (acculturation), or incorporated as a fifth skill.

We understand as stated by Kramsch (2006) that the concept of culture has lost some of its explanatory power since in our global times (cultural) identities are increasingly hybrid and changing because ways of life intertwine and intermingle. Thus, we discuss in the next section how the course and teletandem interactions could provide for the teachers elements for reflection on the meaning of culture in language teaching nowadays.

\section{Teletandem interactions as telepresence}

Our analyses show that teletandem interactions represent a new form of communication that allows for the virtual presence of 
the teletandem partners in each other's contexts, which we named telepresence. That means that the audio, video and chat resources of instant messengers create a videoconferencing context that resembles physical presence. By enabling the person to make him or herself present in their partner's environment through the use of visual and auditory perceptions and through dialogic construction mediated by language, they can bring about different perceptions of each other's culture through shared construction of meanings.

There are a number of factors that account for the enabling of telepresence in a teletandem session. Firstly, good quality videoconferencing is something relatively recent if we think about the development of such technologies. Some of the teachers in our study said that they had never used such tools. The following excerpt demonstrates one of the teacher's comments and reaction when using the computer for online communication in the teletandem laboratory.

Later, we went to the lab, at the university, I found it very rewarding, because I had never talked to someone through the microphone. When I saw my partner from my own group through the camera and looking at my own image as well. I wanted to look good, each movement I made, I could see myself. He did too, I stopped trying to fix my hair, felt a warm sensation. It was great. (Portfolio)

It may be noticed in the teacher's comment that seeing her own image captured by the camera and projected onto the computer screen had an immediate impact on her perception of herself. Telles (2009) discusses the use that teletandem partners' make of the camera for controlling their appearance during interactions stating that it works as a mirror. The mirror is actually a metaphor to describe many of the teletandem processes, such as the opportunity to look at your own self and you own language from a foreign perspective (that of your partners' through interaction), which tends to trigger a reflective process.

In fact, Telles (2009) states that the use of video in teletandem is the fundamental characteristic that makes it so similar to face-to-face tandem and helps partners to solve miscommunication problems, or any other difficulties related to vocabulary or language in general due to the possibility for explorations and behavior observations, such as gestures 
and the environment itself. The teachers in our research commented on these possibilities, as can be seen in the following excerpt.

Sandro: what John said about the issue of image, at first I also/

Fabiana: yeah, I used to look and to see how I was, and she (her partner)

said: "Que guapa estás hoy" (You look pretty today), and so, and then I looked and thought: "Do I, really?"

Everyone laughs.

Fabiana: sometimes I was wearing a night-robe. She: "wow, is it warm there?. Here it is cold." And she was super nice, so she was wearing a scarf and I was wearing a tank top. Then we discussed about the weather, but practically nothing spoken, it was all typed, because if I had to talk, then I felt a little embarrassed.

Sonia: Really? I even talked to her husband, even to the parrot, to Bruno. I talked to everyone.

Beth: I talked to her friends, too.

All teachers speaking together

Keila: the only time I talked (with audio) I spoke to his nephew and his son.

Beth: and then my sister came forward and spoke a bit ...

(...)

Fabiana: it was food, sometimes she prepared some dish and showed me.

(Interview)

In this part of an interview conducted with the teachers at the end of the course, it can be observed that Sandro starts the conversation by remembering a day in class on campus when one of the teacher educators discussed the issue of the use of video in teletandem, and the conversation continues with the teachers putting their views and experiences in this regard. Fabiana talks about her reaction to comments from her partner as they saw each other's images on the computer screen.

It should also be noticed in her account that such interactions were made with video and chat, but not with audio. Fabiana complained several times during the course of technical difficulties in establishing contact through audio and video with her partner; however, another element can be withdrawn from what she says in the interview: a probable fear of oral communication in a foreign language (which was reaffirmed at other times of the interview: "I don't know, because I was 
speaking Spanish to a person who might know more than me. Then it intimidates me a little").

Fabiana was not the only teacher who stated such belief in the legitimation of the knowledge of native speakers over language. Although the Teletandem project does not intend to reaffirm the belief in the native speaker as the ideal informant of language and culture, we believe it is important to raise issues for such debate in the courses where teletandem be offered, since the belief that the native speaker is the only knowledgeable who has legitimacy over language and culture did not seem to be deconstructed or taken to critical reflection by the teachers in our study (Salomão, 2012). In our view, the questioning of this issue must be addressed explicitly in order to generate reflection on this subject. Our suggestion is to focus on readings and presentations of concepts such as the native speaker (Cook, 1999), the intercultural speaker (Byram, 1997) and the multilingual subject (Kramsch, 2009) followed by a discussion of the view of language and culture that underlies each one of them, as well as their relationship with how they direct our teaching practice. ${ }^{2}$

Two other interesting elements mentioned by the teachers in the interview were the use of the image to show the environment, objects, food, etc., and the opportunity to talk to other family members and friends of their partners. In the next two excerpts from Fabiana's and Beth's teletandem interactions with their partners, it can be seen that the image of "the other" transmitted through the webcam extended the range of their presence or "telepresence", enabling partners to use the elements they saw as cues for their conversations or as a strategy to explain what they meant.

Fabiana says: What is this that you are drinking?

Laura says: It is mate. It is a grounded leaf which is wetted.

Fabiana says: Is it good?

Laura says: I love it.

(Interaction - Chat by Fabiana and Laura)

2. See Salomão (2012) for a suggested syllabus with themes and readings to be focused upon in teacher education courses in order to generate reflections about topics such as national culture, essentialism, identity and representation, among others. 
Beth: the consistency of the pudding is that of gelatin Rose: I think we do have it with two hundred grams Beth: Two hundred is too much. Wait a minute I'm going to take a/ (Beth leaves and probably goes to the kitchen)

Beth: Look, this is the quantity of gelatin

Rose: ah

Beth: and look here, this is maria mole

Rosa: Maria mole

Beth: Do you see it?

Rose: (unintelligible)

Beth: Maria mole here is like gelatin, it is soft and has coconut, coconut is written here, look.

Rose: yeah, coconut, I see, yes. I think maybe it exists here.

Beth: if there is, it is easier. And you know that plum can be dried and in sauce, this one has to be in syrup.

(Transcript of interaction Beth and Rose, August 8, 2009, via Skype)

In the first excerpt, Fabiana saw through the webcam that Laura was drinking something, which led her to question her partner about the drink. Although the discussion takes place in the form of chat, the opportunity to see her partner and her environment seemed to generate a greater sense of being next to the person with whom one talks, since the image shows elements that audio or chat alone would not have captured.

As for the second excerpt, Beth was trying to explain what Maria mole is, and she decides to go to the kitchen and grab a box of the product to show Rose, placing it in front of the webcam so that her partner could read the label. The interaction through audio and video brings about elements that enable a form of virtual presence in the environment of one's partner, which approximates the talk of an on-site experience, by creating a context that has characteristics of face-toface interactions.

The opportunity to interact with other members of their partners' families and friends also seemed to extend the range of telepresence. In the following excerpt, Sonia and her partner are talking about a birthday party that Laura is preparing for her husband. However, Sonia at first understands that the party is for Laura's son. After this is cleared up, Laura's husband joins the conversation. 
Sonia: And are children coming, I mean, Diego's friends?

Laura: Diego is my husband

Sonia: Excuse me?

Laura: Diego is my husband, not my son

Sonia: ah, (I mean) your husband's friends, then. Is that it?

Laura: yes

Sonia: tomorrow?

Laura: Yes, they'll come

Sonia: and do you have the habit of making birthday cake or pie?

Laura: Yes

Laura's husband: mama, hello mama

Laura: (laughter)

Sonia: hi

Laura's husband: (unintelligible)

Sonia: What did he say? Hello?

Laura's husband: é minha mãe (He says: she is my mom - attempting to speak Portuguese)

Sonia: Well, it is that in Spain they don't have the habit of making birthday cakes.

Laura: Excuse me?

Sonia: In Spain there is no custom of having a birthday cake for adults, only for children.

Laura: I did not know that.

Sonia: Typically, for a birthday it is like a Sunday meal with the family but they make desserts, but very little cake. All kinds of desserts...

Laura: but in what part, Sonia? I talked to a girl who is Spanish and (unintelligible)

Sonia: ah, well, no, that is customary in my family, I do not know if all...

Laura's husband: Where is your family?

Sonia: In Galicia

Laura's husband: Galicia? Which part?

Sonia: Vigo

Laura's husband: From Vigo? The mother of my (unintelligible) lives in Vigo.

Sonia: Is she from there?

Laura's husband: Where is the largest cathedral?

Sonia: In the center?

Laura's husband: No

Sonia: ah, Santiago de Compostela?

Laura's husband: That's it. Yes, Santiago de Compostela. (unintelligible) from Vigo?

Sonia: Vigo is close to Santiago, about 80 kilometers. My father's 
family lives a little further south. It is a small town next to Vigo. Laura's husband: A village?

Sonia: Yes, a village.

(Transcript of interaction between Sonia and Laura, July 6, 2009, via Skype)

It is interesting to notice that Sonia is, at first, concerned about establishing a comparison between birthday celebrations in Uruguay and Spain - which shows a generalized view of cultural events as pertaining to all citizens in a nation state (a general notion of institutionalized collectivity). It is also noticeable through her words a preference for Spain as the cradle of Spanish language and culture (as with most of the teachers in our research. ${ }^{3}$ ) But her generalized statement about the way Spanish adults celebrate their birthday is challenged by her partner, which leads her to rethink it in terms of a tradition from her own family.

It seems that in teletandem it is the context experienced by partners during interaction that brings about cultural information, which is built up and negotiated through language in the pursuit of mutual understanding. The participants referred to the teletandem context as an opportunity to "participate" in their partner's lives. This participation is due to telepresence, which created a context in which the individual is present in his or her partner's environment (home, lab, Internet cafe) through the placement of the image synchronously (and often the use of audio) and enables them to experience culture from an interactional and dialogical perspective. One of the participants commented on this during the interview. She said, "we talked so much, it was like I was there experiencing the Uruguayan culture, understand?". Some of the teachers mentioned this "different" approach to experiencing culture as opposed to traveling to a certain country as a tourist.

Beth: I think so...

Sonia: You're a spectator in the country, you're a foreigner...

Beth: I did not understand much (when she was visiting Uruguay), then after she spoke, I lived the moment again and she was telling me more. I think it was a live thing, you know when it just clicks? Oh, look, I should have realized this...

Fabiana: while you are there/ 
Keila: it is a lot of information when you are there.

Ana: because when you're a tourist looking at things/

Beth: it is so much you have to look/

Sonia: You're in the house of the person, people, it's different. Now, get to know Spain and have lunch with a Spaniard, it is completely different. You visit the home of a family and listen to everything you hear them talk during breakfast, Christmas, New Year...

Beth: But it's really cool, because it's something live (unintelligible) she is there and I am here and it is as if I were there .... again.

Carla: So it creates this possibility, as if you were there.

Beth: yes

(Interview)

In this interview excerpt, we can observe different views expressed by different teachers as to what it means to "get to know another culture" through travel and through collaborative virtual interactions such as teletandem. Sonia talks about the foreign look that tourists have, once they often stay in the role of a spectator in the foreign country, not participating effectively in interactions with people, but only, as stated by Keila, receiving information. The difference would be the opportunity to enter people's homes and live with them, which for Sonia seems to be possible on a trip if you can "visit the home of a family". For Beth, it also seems possible through telepresence in teletandem interactions. In other words, teletandem interactions should enable the individual to experience culture through interaction, which highlights the role of language in cultural exchanges and not only of physical presence in another country.

In this way, the distance shortened by audio, video and chat tools, used in teletandem sessions, often seems to serve as an approximation to the reality of the other participant, precisely by building up situations dialogically, leading to the feeling of "experience". Consider these excerpts from the portfolio of Luciana in which she recounts a conversation with her partner about funerals and cemeteries, and another one of the teachers accounts during one of the chats on TelEduc:

Her friend's father had died and she had to go to the wake, then we used this opportunity (despite this being a kind of embarrassing subject) to talk about funerals. I learned that panteón is grave and that the older cemeteries are similar to ours, and so are the new ones. 
(19:40:42) Professor from Assis speaks to all: I believe that the interactions have helped me to "find out about Uruguay" and not in an academic way, but because of the experience that I would only have if I were there.

(19:40:53) Beth speaks to all: Technology makes us crazy but it is so stimulating...

(...)

(19:41:05) Sonia speaks to all: I completely agree with you.

(...)

(19:45:34) Professor from Assis speaks to all: it is like being together in the living room drinking tea and chatting. (Chat on TelEduc, "Continuing education and new technologies", 08/05/2009)

We see in Luciana's account that the fact that her partner mentioned she had to go to a wake generated the opportunity to talk about it, which Luciana called "embarrassing". We can say that, by building on a dialogic interaction with her partner, and making comparisons, she may have experienced what going to a funeral and cemetery would be in the foreign country in a similar (but not quite the same) way as if she had actually done such thing in Argentina. It is clear, though, that as with most of the other teachers, she was primarily interested in learning lexicon - which they claimed could be useful in class when students asked about unusual vocabulary. However, we can see a potential for the interactions to generate the experience of culture through dialogical construction, which, if combined to reflection in the classroom, may bring about opportunities for the reformulation of conceptions and beliefs, especially concerning collective and individual elements present in the concept of culture. The central question would be to go beyond the notion of seeking cultural differences, so as to try to enter a level of reflection in which we seek to understand the meanings that such elements acquire in certain cultures, both at the collective level, as a society, and at the individual level, pierced by multifaceted identity elements, compounded by socio-historical, political and economic factors.

Kramsch and Thorne (2002) point out that we should look to digital spaces as social spaces and the paradox of the global communication networks today, highlighting the fact that they encourage alienation by 
reducing face-to-face contact while providing a nexus of connectivity, social interaction and community formation (albeit in new formats). Telepresence does not seem to reduce face-to-face contact, but modify it by adding new elements through the means of communication used (audio, video or chat), which differs from the experience of physical presence in the environment. Thus, the padarox found in this study lies in the fact that the very technologies that have created an era of rapid access to information and, we might say, an oversimplification of things can at the same time provide contacts and interactions (such as telepresence) that may help us understand the complexity of human beings and their multiple identities.

\section{Conclusion}

The technological expansion of audio and video tools for online communication enabled contact with other peoples and cultures without geographical displacement, which has the potential to change our social relations and the way we see and interpret the world in which we live. This has made us think about the implications of the contact afforded by teletandem interactions for language teaching and teacher education.

It is widely known that many educational practices in foreign language teaching still seem to be dominated by an essentialist view of culture, characterized by problematic and/or imaginary stereotypes of national cultures. However, the new tools and applications for distance communication on the Internet have contributed to the increase of communicative practices between individuals of different cultural backgrounds by bringing about the complexity of the pragmatism of intercultural encounters. We understand that this should also bring impacts to the way we understand and teach culture in language learning.

In relation to foreign language teachers, numerous studies aim to constitute their (professional) identities based on the movements generated by the sociocultural transformations of postmodernism (Magalhães et al., 2006). Thus, we believe it is important to reflect upon issues that constitute the relationship between non-native speaker teachers and the target language and culture that they teach. These often 
seem to be in a position of antagonism to their perceptions regarding their own native language and culture, creating the idea that the only possible options in foreign language teaching are the assimilation or replacement of values and meanings.

Our findings point to the need to problematize in teacher education the belief of the native speaker as the legitimate and ideal informant of language and culture in order to discover (or uncover) the way conceptions of culture interact with the belief of many teachers about the need for on-site experience to legitimize their knowledge of the target language and culture. They also indicate the need for a review of the language teaching knowledge base regarding intercultural communication and the teaching and learning of culture, which should spur discussions grounded in real world interaction and nurtured by technological tools, in order to generate the opportunity for dialogically undergoing experiences, such as the ones provided by telepresence in teletandem. After the interactions, teachers' views of culture also seemed to incorporate aspects of culture as an interpersonal process, instead of the factual and static view that was previously predominant.

Therefore, teacher education programs should consider the possibility of conjugating theory and reflective practice through the use of videoconferencing tools, making use of the pragmatism afforded by online telecollaboration in order to allow teachers to experience culture rather than only learn (and thus teach) facts about it, and to understand the way we bring with us our discourses and feelings of culture and negotiate these in interaction.

We also suggest that other studies be conducted focusing on complex relationship between the concept of culture in language teaching and how online intercultural encounters may challenge static and factual views by looking at them through a perspective of dynamicity, subjectivity and senses of belonging, and deconstructing stereotypical images of people from the media and popular discourse.

Received in March, 2015

Accepted in August, 2015

E-mail:

ana.salomao@fclar.unesp.br 


\section{References}

ANDRÉ, M.E.D.A. 2000. Etnografia da prática escolar. 4.ed. Campinas: Papirus.

Bogdan, R.D.; BikLEn, S.K. 1982. Qualitative research for education. Boston: Allyn and Bacon.

Byram, M. 1997. Teaching and Assessing Intercultural Communicative Competence. Clevedon: Multilingual Matters.

Chapelle, C.A. 2006. Foreword. In: P. Hubbard \& M. Levy. Teacher Education in CALL. Amsterdam/Philadelphia: Benjamin Publishing Company.

Cook, V. 1999. Going beyond the native speaker in language teaching. Tesol Quarterly 33/2: 185-209.

ERICKSON, F. 1986. Qualitative methods in research on teaching. In: M.C. Wittrock (ed.). Handbook of research on teaching. 3. ed. New York: MacMillan.

Hall, D.R.; Knox, S. 2009. Language Teacher Education by Distance. In: A. Burns \& J.C. Richards (eds.). Second language teacher education. Cambridge: Cambridge University Press.

Holliday, A. R. 2005. The Struggle to Teach English as an International Language. Oxford: Oxford University Press.

Holliday, A.; Hyde, M.; Kullman, J. 2010. Intercultural communication: an advanced resource book for students. 2. ed. New York: Routledge.

JoHnson, K.E. 2009. Second Language Teacher Education: A Sociocultural Perspective. 1.ed. New York: Routledge.

KramsCh, C. 2006. Culture in language teaching. In: K. Brown (ed.). Encyclopedia of Language and Linguistics. Vol. 3. 2nd edition. Oxford: Elsevier Science.

2009. Cultural perspectives on language learning and teaching.

In: K. Knapp \& B. Seidlhofer (eds.). Handbook of foreign language communication and learning. Berlin: Mouton de Gruyter.

2011. The symbolic dimensions of the intercultural. Language Teaching 44: 354-367.

; Thorne, S.L. 2002. Foreign language learning as global communicative practice. In: D. Block \& D. Cameron (eds.). Globalization and language teaching. New York: Routledge.

Kumaravadivelu, B. 2006. A Linguística Aplicada na era da Globalização.

In: L.P. Moita Lopes (org.). Por uma linguística aplicada INdisciplinar.

São Paulo: Parábola Editorial.

2008. Cultural Globalization and Language Education. USA:

Yale University Press. 
LANTOLF, J.P. 2000. Sociocultural theory and second language learning. Oxford: Oxford University Press.

Magalhães, I. et al. (org.). 2006. Práticas identitárias: língua e discurso. São Carlos: Claraluz.

Mcdonough, J.; Mcdonough, S. 1997. Research Methods for English Language Teachers. London: Arnold.

Rajagopalan, K. 2003. Por uma linguística crítica: linguagem, identidade e a questão ética. São Paulo: Parábola.

Risager, K. 2006. Language and Culture: Global Flows and Local Complexity. Clevedon: Multilingual Matters.

. 2007. Language and Culture Pedagogy: from a national to a transnational paradigm. Clevedon: Multilingual Matters.

SAlomão, A. C. B. 2012. A cultura e o ensino de língua estrangeira: perspectivas para a formação continuada no projeto Teletandem Brasil. Tese de Doutorado. 270 f. São José do Rio Preto, UNESP, Instituto de Biociências, Letras e Ciências Exatas.

; MeneGhin, C. M. 2014. Crenças, pressupostos e conhecimentos de professores em serviço sobre língua(gem) em um curso de formação continuada. Signum. Estudos de Linguagem, v. 17, p. 272-297.

Silverman, D. 2000. Doing qualitative research: a practical handbook. London: Sage.

Telles, J.A.; Vassallo, M.L.A. 2006. Foreign language learning intandem: Theoretical principles and research perspectives. The ESPecialist 27/1: 83-118.

Telles, J.A. 2009. Do we really need a webcam? - The uses that foreign language students make out of webcam images during teletandem sessions. Letras \& Letras 25/2: 65-79.

Vassallo, M.L.; Telles, J.A. 2006. Foreign language learning in-tandem: Teletandem as an alternative proposal in CALLT. The ESPecialist 27/2: 189-212.

Vygotsky, L.S. 1994. A formação social da mente. 5. ed. São Paulo: Martins Fontes. 